\title{
COVID-19, Angiotensin Receptor Blockers, and the Brain
}

\author{
Juan M. Saavedra ${ }^{1}[$ \\ Received: 8 April 2020 / Accepted: 2 May 2020 / Published online: 8 May 2020 \\ (c) Springer Science+Business Media, LLC, part of Springer Nature 2020
}

The abundant scientific information on the COVID-19 pandemic we receive through academic publications and correspondence, as well as through social media, is sometimes preliminary, incomplete, and contradictory. For this reason, it is dangerous to rush to interpret those early results. This could backfire and unwittingly feed a mistrust of the stringent scientific method.

While fast dissemination of information in the form of commentaries and publications without prior review by experts has its merits in this state of emergency, erroneous results and recommendations find their way to the general population, frequently without the expertise to accurately assess the information presented. In this time of uncertainty and fear, it is difficult to remain objective and to critically evaluate the scientific merit of the available new information.

The peer review system by experts has been and needs to continue to be a pillar of scientific progress. It is important to point out that information from well-regarded previously published peer-reviewed publications on previously known Severe Acute Respiratory Syndrome (SARS) coronavirus is used as the basis to further explore the SARS-CoV-2 mechanisms of infection and to search for novel therapies.

This Editorial intends to highlight recent reports of neurological complications of COVID-19, to describe the pleiotropic protective properties of Angiotensin Receptor Blockers (ARBs) in multiple organs including the brain and the lung, to clarify contradictory recommendations regarding the present use of ARBs in patients affected with cardiovascular and other illnesses that may later become COVID-19 comorbidities, to describe the complexities of ACE2 on its dual role of SARS-CoV-2 receptor and as a major protective mechanism in lung injury, and to suggest future studies necessary to definitively determine the potential therapeutic value of ARB treatment in COVID-19 patients.

Juan M. Saavedra

juan.saavedra@georgetown.edu

1 Department of Pharmacology and Physiology, Georgetown University Medical Center, 3900 Reservoir Road, NW, Washington, DC 20057, USA

\section{SARS-CoV-2 Injures the Brain}

The SARS-CoV-2, responsible for the current coronavirus disease COVID-19, not only affects the lung but also targets the nervous system. SARS-CoV-2 may reach the brainstem through a neural route from lung chemoreceptors, severely affecting the cardiorespiratory center ( $\mathrm{Li}$ et al. 2020a). This suggests that the acute respiratory failure in some COVID-19 patients may have a central origin ( $\mathrm{Li}$ et al. 2020a). SARS-CoV-2 may also injure olfactory nerve terminals in the nasal cavity, explaining both the anecdotal and the recently published observations of associated decreased sense of smell in COVID-19 patients (Yeager 2020a; Rabin 2020; Lechien et al. 2020). It is of note that olfactory deficits have been previously reported for several viral infections including coronavirus (Suzuki et al. 2007), and are characteristic of neurodegenerative disorders such as Alzheimer's and Parkinson's diseases (Marin et al. 2018).

In addition, SARS-CoV-2 may reach the cerebral vasculature through the general circulation (Baig et al. 2020), breaching the blood-brain barrier and invading and injuring the brain parenchyma. SARS-CoV-2 may bind to its receptor Angiotensin Converting Enzyme 2 (ACE2) expressed in endothelial cells of cerebral capillaries (Peña Silva et al. 2012), and within the brain parenchyma in both neurons and microglia (Yamagata et al. 2020). Since the blood-brain barrier is disrupted in hypertension (Setiadi et al. 2018) and hypertension is a frequent comorbidity for COVID-19, these patients may have a higher risk of cerebral complications.

Initial reports confirm that cerebrovascular diseases are very frequent in patients affected by COVID-19 and their prevalence increases threefold in severe cases (Liu et al. 2020b, Li et al. 2020d; Chen et al. 2020). It was also reported that $36 \%$ of patients diagnosed with COVID-19 presented neurological manifestations (Mao et al. 2020), and headache, nausea, vomiting, and confusion were frequently observed (Li et al. 2020c; Chen et al. 2020). Recent observational studies confirmed that cerebrovascular disease, including ischemic stroke, cerebral venous thrombosis, and cerebral 
hemorrhage was common in elderly COVID-19 patients ( $\mathrm{Li}$ et al. 2020c; Poyiadji et al. 2020; Sharifi-Razavi et al. 2020).

While part of this higher representation of cerebral disorders in patients affected by SARS-CoV-2 may be correlative to the age distribution, biased towards elderly patients, clinical studies showed that coronavirus has a tropism for the central nervous system (Carod-Artal 2020; Baig et al. 2020; $\mathrm{Li}$ et al. 2020a; Mao et al. 2020) and that acute cerebral alterations such as hemorrhagic necrotizing encephalopathy occur in COVID-19 patients due to direct viral invasion of the nervous system (Markus and Brainin 2020; Li et al. 2020c; Poyiadji et al. 2020; Sharifi-Razavi et al. 2020).

These observations should not be surprising. Other coronaviruses, such as the mouse hepatitis virus (MHV), also infect the brain; its JHM strain is highly neurovirulent (Weiss and Navas-Martin 2005) and SARS-CoV was reported to be extremely neurotoxic in animal models (Netland et al. 2008). There is ample evidence of association of several viral infections of the brain with increased prevalence of Alzheimer's and Parkinson's diseases (Redhead et al. 2018; Gamboa et al. 1974) and we may detect, in the future, an increased incidence of neurodegenerative disorders in patients previously affected by COVID-19.

For these reasons, while waiting for the development of an effective vaccine and novel therapeutic agents, it is imperative to consider repurposing available drugs to treat and prevent COVID-19-associated brain ailments.

\section{Potential for ARBs to Modulate COVID-19 Pathophysiology}

One such class are the Angiotensin Receptor Blockers (ARBs). Angiotensin II AT1 receptor (AT1R) stimulation drives the circulatory and local Renin-Angiotensin Systems (RAS), involved in the regulation of multiple functions in most organs (Paul et al. 2006; Rein and Bader 2017; Takimoto-Ohnishi and Murakami 2019) and including the lung (Jia 2016). Increased RAS activity with enhanced AT1R stimulation is a major injury factor affecting the brain, the cardiovascular and renal function, lipid and glucose metabolism, and the immune system (Paul et al. 2006; Rein and Bader 2017; Takimoto-Ohnishi and Murakami 2019; Jia 2016). In addition, overactivity of AT1R promotes inflammatory lung disease (Jia 2016).

ARBs, effectively blocking AT1R and initially developed to treat hypertension, exhibit unique pleiotropic protecting effects beyond their antihypertensive properties (Saavedra 2017). ARBs reduce inflammation and endothelial and epithelial dysfunction in many organs including the lung, protecting its endothelial barrier integrity (Fedson 2016). There is substantial clinical evidence indicating that ARBs protect the lung from severe injury associated to pneumonia, sepsis, influenza, and chronic pulmonary disease, improving overall pulmonary health (Fedson 2016; Mortensen et al. 2012; Soto et al. 2017; Kim et al. 2016; Chang et al. 2015) and reduce SARS coronavirus-induced lung injury (Kuba et al. 2005). Furthermore, mortality was reduced in patients previously treated with ARBs for cardiovascular disorders and later hospitalized for pneumonia (Fedson 2016). Thus, it is reasonable to speculate that ARBs may ameliorate pneumonia in COVID-19 patients, since recent studies have reported that ARBs improve the overall clinical outcome of COVID19 patients with hypertension (Meng et al. 2020).

In addition, ARBs directly protect mitochondrial function, maintain insulin sensitivity and energy metabolism, protect lipid metabolism, and normalize the coagulation cascade, properties considered to benefit patients with acute and chronic critical disorders (Jia 2016, Gurwitz 2020, Fedson 2016). For these reasons, ARBs are successfully used not only as first-line antihypertensives but also for the treatment of diabetes, kidney disease, congestive heart failure, and cerebrovascular disorders (Chrysant 2006).

The spectrum of illnesses considered to be candidates for ARB therapy is wide and increasing. Preclinical experiments demonstrated that ARBs protect cerebral blood flow and blood-brain barrier function, reduce brain inflammation, protect cognition, and reduce anxiety and stress (Schmieder 2005; Hosomi et al. 2013; Villapol and Saavedra 2015; Saavedra 2017; Rodriguez-Perez et al. 2018; Elkahloun et al. 2019). The hypothesis that ARBs may be effective for the treatment of diseases of the brain is being tested; there are over 20 clinical trials designed to investigate the therapeutic effects of ARBs on cerebrovascular disorders, psychiatric ailments, Alzheimer's disease and cognition, and many other clinical trials address the possible efficacy of ARB treatment in an ever-expanding number of diseases (https://clinicaltr ials.gov/).

From the above, and although prevalence data are not available, it is reasonable to assume that a significant proportion of patients affected with cardiovascular, brain, and metabolic disorders are currently medicated with ARBs. And since these illnesses are frequently comorbidities in COVID-19 patients (Li et al. 2020b, c, d; Chen et al. 2020), we can make a reasonable assumption that many COVID19 patients have been medicated with ARBs at the time of their diagnosis.

At first glance, it is also reasonable to hypothesize that COVID-19 patients under previous ARB treatment for comorbid diseases may benefit from the continuation of this therapy, and that their symptoms may be moderated. Recent reports demonstrated that continuation of previous ARB therapy decreased morbidity and mortality in COVID-19 patients (Liu et al. 2020a; Meng et al. 2020), supporting this hypothesis. However, more controlled studies including thousands of patients are needed to reach a 
definite conclusion not only on the safety but also on the benefit of the continuation of established ARB therapy during COVID-19.

In case that the safety and benefit of continuation of ARB therapy in non-hospitalized and hospitalized patients is confirmed by definite clinical studies and data analysis, ARB treatment may be considered for those patients suffering from COVID-19 comorbidities such as hypertension and not medicated with ARBs prior to COVID-19 diagnosis. This proposal is substantiated by the report of marked increases in Angiotensin II plasma levels in COVID-19 patients, linearly associated to viral load and lung injury (Liu et al. 2020b). These observations strongly suggested that RAS activity was enhanced and AT1 receptors were overstimulated in these patients, probably as the result of direct effects of SARSCoV-2, critical worsening of overall tissue inflammation and COVID-19 comorbidities, associated with intense mental and physical stress. Based on these findings, it has been recommended to repurpose ARBs as part of the therapeutic arsenal for COVID-19 (Liu et al. 2020b; Gurwitz 2020). A recent article published in The Scientist and based on interviews with experts in the field summarized the rationale for the use of ARBs as COVID-19 treatment (Yeager 2020b), and a recent article already describes in detail the beneficial effects of ARB therapy in COVID-19 patients (Liu et al. 2020a).

To answer this question, at present there are 24 clinical studies to determine the effects of the initiation of ARB therapy in non-hospitalized and hospitalized COVID-19 patients (https://clinicaltrials.gov/ct2/results?cond=COVID $-19 \&$ term $=$ angiotensin + receptor + blockers $\&$ cntry $=\&$ state $=\&$ city $=\&$ dist $=)$. Only the results of these clinical trials will establish whether addition of ARBs to the therapeutic arsenal of COVID-19 patients is of significant clinical benefit.

\section{Initial Arguments Against the Use of ARBs}

However, some published commentaries (Fang et al. 2020; Diaz 2020) recommended, as a preventive measure, to discontinue the use of ARBs in the general population, even when successfully prescribed for the treatment of cardiovascular, cerebrovascular, or metabolic disorders, on the grounds that ARB therapy may actually enhance the risk of COVID-19. This recommendation was widely echoed in social media. The authors based their recommendation on the discovery that ARBs upregulate ACE2, a SARS-CoV-2 receptor, and they hypothesize that ARBs may enhance viral uptake and virulence, without offering any evidence that this may be the case. Neither Diaz (2020) nor Fang et al. (2020) considered the substantial literature demonstrating that enhanced ACE2 expression is protective, not only for the lung but also for other organs. Fang et al. (2020) argued that ARBs may be replaced by other antihypertensives such as calcium-blocking agents, without considering that these compounds lack the pleiotropic protective characteristics of ARBs. Abruptly replacing ARBs in patients affected with hypertension, heart failure, or previous myocardial infarct with other medications may expose the patients to significant risks and may worsen their prognosis (Vaduganathan et al. 2020). A detailed rebuttal of Diaz (2020) and Fang et al. (2020) recommendations has been recently published elsewhere (Saavedra 2020). Recommendations not to withdraw ARBs when medically prescribed have been echoed in several recent publications (Gurwitz 2020; Patel and Verma 2020; South et al. 2020).

Arguments for and against the use of ARBs during the COVID-19 pandemic have been also applied to administration of Angiotensin-Converting Enzyme inhibitors (ACEI), compounds that reduce AT1R overstimulation by decreasing Angiotensin II production, and the arguments have been generally addressed without distinction for both classes of compounds. However, some studies reported that ARBs, when compared to ACEIs, were associated with lower rates of severe pneumonia and mortality in patients with chronic pulmonary disease (Lai et al. 2018) and in patients suffering from severe acute pneumonia (Chang et al. 2015).

\section{ACE2 as a Therapeutic Target in Fighting SARS-CoV-2 Infection}

ACE2 is a multispecific enzyme. Although ACE2, located in the surface of lung alveolar epithelial cells among others (Hamming et al. 2004; Zou et al. 2020) is a receptor for SARS coronaviruses including SARS-CoV-2 (Yan et al. 2020; Shang et al. 2020), it is also a demonstrated protective factor for SARS in the lung (Jia 2016). ACE2 cleaves Angiotensin II into Ang (1-7), part of the ACE2/Angiotensin (1-7)/Mas axis, a proposed protective mechanism balancing RAS overstimulation, and this system is stimulated by ARBs (Ren et al. 2019). The demonstrated reduction on ACE2 expression in elderly individuals (AlGhatrif et al. 2020), associated to upregulation of the RAS and the Angiotensin inflammatory pathway (Rodriguez Prestes et al. 2017, Conti et al. 2012) may contribute to their increased risk for COVID-19, another reason to consider ARBs as a therapeutic avenue for the disease.

Decreased ACE2, systemically and/or locally, has been proposed to be an important contributor to the pathogenesis of many diseases including inflammatory lung disease (Jia 2016; Fedson 2016). More importantly, ACE2 protects lung function (Fedson 2016; Yu et al. 2016). ACE2 circulates in the blood (Wysocki et al. 2010). Membrane-associated ACE2 is shed by ADAM17 to the extracellular media (Xu et al. 2016). Soluble ACE2 is enzymatically active and 
partially inhibits coronavirus entry into target cells (Jia et al. 2009). For this reason, ACE2 administration has long been considered as treatment for SARS viruses (Jia 2016).

The use of clinical-grade soluble human ACE2 was recently proposed to block SARS-CoV-2 infection (Monteil et al. 2020; Batlle et al. 2020). A recent article published in The Scientist describes expert recommendations to use ACE2 administration as a treatment for COVID-19, and in Europe, regulatory approval for a Phase II clinical trial to use human ACE2 for the treatment of COVID-19 was recently obtained (Yeager 2020b).

\section{The Complexity of SARS Coronaviral Entry into the Cells}

SARS viral entry into the cells is not only dependent on ACE2, but also on several peptidases acting as co-receptors for SARS coronaviruses (Qi et al. 2020; Hoffmann et al. 2020; Jeffers et al. 2004; Matsuyama et al. 2010; Kawase et al. 2012). Although the role of these co-receptors has not been investigated for SARS-CoV-2 infection, they were reported to be essential for ACE2 participation in the entry of other coronavirus into the cells (Qi et al. 2020; Hoffmann et al. 2020; Jeffers et al. 2004; Matsuyama et al. 2010; Kam et al. 2009; Adedeji et al. 2013). The influence of ARBs on the role of coronavirus co-receptors has not been studied.

Another example of the complexity of ACE2 regulation and its role in viral infections is the recent report demonstrating that ACE2 is an interferon-stimulated gene in human airway epithelial cells, since interferons enhance $A C E 2$ gene expression (Ziegler et al. 2020). However, the study did not clarify whether this mechanism is harmful to the cells or beneficial.

In addition, the SARS coronavirus-ACE2 pathway is associated with chemokine (C-C motif) ligand 2 (CCL2) (Chen et al. 2010) and the production of this chemokine is reduced by ARBs (Clancy et al. 2014). Furthermore, ACE2 not only cleaves circulating Angiotensin II but also hydrolyses several peptides such as dynorphin, apelin, and bradykinin (Warner et al. 2004). The pathophysiological significance of these relationships has not been fully investigated.

\section{Abstract and Recommendations}

1. Well-regarded clinical studies demonstrate that the SARS-CoV-2 virus affects the function of many organs besides the lung, including the brain. Neurological examinations are needed for all patients infected with SARS-CoA-2, whether symptomatic for COVID-19 or not, and certainly during hospitalization. COVID-19 patients should be considered a group at higher risk for brain disorders, even after recovery from the disease. Long-term neurologic follow-up after recovery from COVID-19 will reveal whether this illness is associated with neurodegenerative conditions susceptible of early treatment. Mental health support should be offered to COVID-19 patients and their families after recovery from the critical stage of their illness.

2. It has been conclusively demonstrated that treatment with ARBs protects patients and ameliorates the consequences of cerebral, cardiovascular, metabolic, and renal disorders that later become frequent COVID-19 comorbidities. ARBs have been shown to protect lung function, reduce the severity of pneumonia, and alleviate chronic pulmonary disease. These findings strongly support not to discontinue ARB treatment when medically prescribed. Abrupt ARB withdrawal in these patients will expose them to a significant risk of serious complications.

3. To definitely answer the recommendations to withdraw ARB treatment from patients already medicated with ARBs for cardiovascular and other disorders, we would need additional studies, many of them already under way. First, we need clear and conclusive evidence that ARB treatment does not predispose patients to SARSCoV-2 infection. Are patients under ARB treatment less likely to be infected with SARS-CoV-2? To answer this question, we would need population studies and data analysis to establish that the patient population treated with ARBs is not at higher, but instead at lower risk of SARS-CoV-2 infection. Furthermore, are patients infected with SARS-CoV-2 more likely to be asymptomatic if they have been previously treated with ARBs? The answers to these questions will require clinical studies and data analysis not presently under consideration.

4. At present, even more pressing studies are under way to determine the effect of previous ARB treatment that has been continued during hospitalization of COVID-19 patients. The presence or absence of ARB therapy in COVID-19 patients is now carefully documented and monitored in many clinical centers, including determination of ARB protection against COVID-19-induced hypertension. We need to conclusively determine whether continuation of ARB treatment in COVID19 non-hospitalized or hospitalized patients is beneficial, reducing progression, accelerating recovery, and decreasing mortality. Several preliminary analyses demonstrate that ARBs reduce the severity and mortality of COVID-19 patients (see details in the text) and more definitive results are likely to be published momentarily. These data analysis will also discover whether discontinuation of ARB therapy prior to COVID-19 diagnosis influences the progression of the disease. 
5. A most important question remaining is whether de novo ARB administration to COVID-19 patients could be therapeutically efficacious. There are at present (0428-2020) at least 24 new carefully designed controlled clinical trials looking at de novo ARB administration to COVID-19 patients testing this hypothesis and including the effects of discontinuation of ARB therapy in COVID-19 patients. https://clinicaltrials.gov/ct2/ results? cond=COVID-19\&ter $\mathrm{m}=$ angiotensin + recep tor+blockers $\&$ cntry $=\&$ state $=\&$ city $=\&$ dist $\equiv$

6. While clinical studies as the ones described above are of immediate value, experimental research will be needed to clarify the effects of ARBs on SARS-CoV-2 entry into the cells and its virulence, and to establish the effects of ARBs not only on ACE2 but also on other coronavirus co-receptors and on associated signal transduction mechanisms.

\section{Conclusions}

Based on available evidence, patients medicated with ARBs by their physicians should continue their medications as prescribed. Similar recommendations have been advanced by the European Society of Cardiology (2020) and the American Heart Association (2020). If we obtain a clear, definitive, and accepted demonstration that ARBs are not harmful but rather protective against COVID-19, instead of withdrawing these medicines from those affected with hypertension and other possible COVID-19 comorbidities, ARBs should be included in the therapeutic arsenal of patients not currently treated with these compounds.

Funding JMS has not been funded by any source during the preparation of this manuscript.

\section{Compliance with Ethical Standards}

Competing interests JMS does not report any competing interests.

\section{References}

Adedeji AO, Severson W, Jonsson C, Singh K, Weiss SR, Sarafianos SG (2013) Novel inhibitors of severe acute respiratory syndrome coronavirus entry that act by three distinct mechanisms. J Virol 87:8017-8028. https://doi.org/10.1128/JVI.00998-13

AlGhatrif M, Cingolani O, Lakatta EG (2020) The Dilemma of Coronavirus Disease 2019, aging, and cardiovascular disease: insights from cardiovascular aging science. JAMA Cardiol. https://doi. org/10.1001/jamacardio.2020.1329
American Heart Association. HFSA/ACC/AHA statement addresses concerns re: using RAAS antagonists in COVID-19. https://profe ssional.heart.org/professional/ScienceNews/UCM_505836_ HFSAACCAHA-statement-addresses-concerns-re-using-RAASantagonists-in-COVID-19.jsp. Accessed 20 Mar 2020

Baig AM, Khaleeq A, Ali U, Syeda H (2020) Evidence of the COVID19 Virus targeting the CNS: tissue distribution, host-virus interaction, and proposed neurotropic mechanisms. ACS Chem Neurosci 11:995-998. https://doi.org/10.1021/acschemneuro.0c00122

Batlle D, Wysocki J, Satchell K (2020) Soluble angiotensin-converting enzyme 2: a potential approach for coronavirus infection therapy? Clin Sci (Lond) 134:543-545. https://doi.org/10.1042/CS202 00163

Carod-Artal FJ (2020) Neurological complications of coronavirus and COVID-19. Rev Neurol 70:311-322. https://doi.org/10.33588/ rn.7009.2020179

Chang CH, Lin JW, Ruan SY, Lee YC, Wu LC, Lin MS, Lai MS (2015) Comparing individual angiotensin-converting enzyme inhibitors with losartan in the risk of hospitalization for pneumonia and related mortality: a nationwide cohort study. J Hypertens 33(3):634-642. https://doi.org/10.1097/HJH.0000000000000438

Chen IY, Chang SC, Wu HY, Yu TC, Wei WC, Lin S, Chien CL, Chang MF (2010) Upregulation of the chemokine (C-C motif) ligand 2 via a severe acute respiratory syndrome coronavirus spike-ACE2 signaling pathway. J Virol 84:7703-7712. https://doi.org/10.1128/ JVI.02560-09

Chen N, Zhou M, Dong X, Qu J, Gong F, Han Y, Qiu Y, Wang J, Liu Y, Wei Y, Xia J, Yu T, Zhang X, Zhang L (2020) Epidemiological and clinical characteristics of 99 cases of 2019 novel coronavirus pneumonia in Wuhan, China: a descriptive study. Lancet 395:507-513. https://doi.org/10.1016/S0140-6736(20)30211-7

Chrysant SG (2006) Clinical experience with the use of angiotensin receptor blockers in patients with cardiovascular, cerebrovascular and renal diseases. Curr Clin Pharmacol 1:139-146. https://doi. org/10.2174/157488406776872532

Clancy P, Koblar SA, Golledge J (2014) Angiotensin receptor 1 blockade reduces secretion of inflammation associated cytokines from cultured human carotid atheroma and vascular cells in association with reduced extracellular signal regulated kinase expression and activation. Atherosclerosis 236:108-115. https://doi. org/10.1016/j.atherosclerosis.2014.06.011

Conti S, Cassis P, Benigni A (2012) Aging and the renin-angiotensin system. Hypertension 60:878-883. https://doi.org/10.1161/ HYPERTENSIONAHA.110.155895

Diaz JH (2020) Hypothesis: angiotensin-converting enzyme inhibitors and angiotensin receptor blockers may increase the risk of severe COVID-19. J Travel Med. https://doi.org/10.1093/jtm/taaa041

Elkahloun AG, Rodriguez Y, Alaiyed S, Wenzel E, Saavedra JM (2019) Telmisartan protects a microglia cell line from LPS injury beyond AT1 receptor blockade or PPAR $\gamma$ activation. Mol Neurobiol 56:3193-3210. https://doi.org/10.1007/s12035-018-1300-9

European Society of Cardiology (2020) Position statement of the ESC Council on Hypertension on ACE-inhibitors and angiotensin receptor blockers. https://www.escardio.org/Councils/Counc il-on-Hypertension-(CHT)/News/position-statement-of-the-esccouncil-on-hypertension-on-ace-inhibitors-and-ang. Accessed 20 Mar 2020

Fang L, Karakiulakis G, Roth M (2020) Are patients with hypertension and diabetes mellitus at increased risk for COVID-19 infection? Lancet Respir Med 8(4):e21. https://doi.org/10.1016/S2213 $-2600(20) 30116-8$

Fedson DS (2016) Treating the host response to emerging virus diseases: lessons learned from sepsis, pneumonia, influenza and Ebola. Am Transl Med 4:421. https://doi.org/10.21037/ atm.2016.11.03 
Gamboa ET, Wolf A, Yahr MD, Harter DH, Duffy PE, Barden H, Hsu KC (1974) Influenza virus antigen in postencephalitic parkinsonism brain: detection by immunofluorescence. Arch Neurol 31:228-232. https://doi.org/10.1001/archneur.1974.0049040004 2003

Gurwitz D (2020) Angiotensin receptor blockers as tentative SARSCoV-2 therapeutics. Drug Dev Res. https://doi.org/10.1002/ ddr. 21656

Hamming I, Timens W, Bulthuis ML, Lely AT, Navis G, van Goor H (2004) Tissue distribution of ACE2 protein, the functional receptor for SARS coronavirus. A first step in understanding SARS pathogenesis. J Pathol 203:631-637. https://doi.org/10.1002/ path. 1570

Hoffmann M, Kleine-Weber H, Schroeder S, Krüger N, Herrler T, Erichsen $\mathrm{S}$ et al (2020) SARS-CoV-2 cell entry depends on ACE2 and TMPRSS2 and is blocked by a clinically proven protease inhibitor. Cell. 181:271-280.e8. https://doi.org/10.1016/j. cell.2020.02.052

Hosomi N, Nishiyama A, Matsumoto M (2013) Do RAS inhibitors protect the brain from cerebral ischemic injury? Curr Hypertens Rev 9:86-92. https://doi.org/10.2174/15734021113099990002

Jeffers SA, Tusell SM, Gillim-Ross L, Hemmila EM, Achenbach JE, Babcock GJ, Thomas WD Jr, Thackray LB, Young MD, Mason $\mathrm{RJ}$, Ambrosino DM, et al (2004) CD209L (L-SIGN) is a receptor for severe acute respiratory syndrome coronavirus. Proc Natl Acad Sci USA 101:15748-15753. https://doi.org/10.1073/pnas.04038 12101

Jia H (2016) Pulmonary angiotensin-converting enzyme 2 (ACE2) and inflammatory lung disease. Shock 46:239-248. https://doi. org/10.1097/SHK.0000000000000633

Jia HP, Look DC, Tan P, Shi L, Hickey M, Gakhar L, Chappell MC, Wohlford-Lenane C, McCray PB Jr (2009) Ectodomain shedding of angiotensin converting enzyme 2 in human airway epithelia. Am J Physiol Lung Cell Mol Physiol 297:L84-96. https://doi. org/10.1152/ajplung.00071.2009

Kam YW, Okumura Y, Kido H, Ng LF, Bruzzone R, Altmeyer R (2009) Cleavage of the SARS coronavirus spike glycoprotein by airway proteases enhances virus entry into human bronchial epithelial cells in vitro. PLoS ONE 4:e7870. https://doi.org/10.1371/ journal.pone. 0007870

Kawase M, Shirato K, van der Hoek L, Taguchi F, Matsuyama S (2012) Simultaneous treatment of human bronchial epithelial cells with serine and cysteine protease inhibitors prevents severe acute respiratory syndrome coronavirus entry. J Virol 86:6537-6545. https ://doi.org/10.1128/JVI.00094-12

Kim J, Lee JK, Heo EY, Chung HS, Kim DK (2016) The association of renin-angiotensin system blockades and pneumonia requiring admission in patients with COPD. Int $\mathbf{J}$ Chron Obstruct Pulmon Dis 11:2159-2166. https://doi.org/10.2147/COPD.S104097

Kuba K, Imai Y, Rao S, Gao H, Guo F, Guan B, Huan Y, Yang P, Zhang Y, Deng W, Bao L, Zhang B, Liu G, Wang Z, Chappell M, Liu Y, Zheng D, Leibbrandt A, Wada T, Slutsky AS, Liu D, Qin C, Jiang C, Penninger JM (2005) A crucial role of angiotensin converting enzyme 2 (ACE2) in SARS coronavirus-induced lung injury. Nat Med 11:875-879. https://doi.org/10.1038/nm1267

Lai CC, Wang YH, Wang CY, Wang HC, Yu CJ, Chen L (2018) Comparative effects of angiotensin-converting enzyme inhibitors and angiotensin II receptor blockers on the risk of pneumonia and severe exacerbations in patients with COPD. Int J Chron Obstruct Pulmon Dis 13:867-874. https://doi.org/10.2147/COPD.S158634
Lechien JR, Chiesa-Estomba CM, De Siati DR et al (2020) Olfactory and gustatory dysfunctions as a clinical presentation of mild to moderate forms of the Coronavirus Disease (COVID-19): A Multicenter European Study. Eur Arch Otorhinolaryngol. https://doi. org/10.1007/s00405-020-05965-1

Li YC, Bai WZ, Hashikawa TJ (2020a) The neuroinvasive potential of SARS-CoV2 may play a role in the respiratory failure of COVID19 patients. Med Virol. https://doi.org/10.1002/jmv.25728

Li J, Wang X, Chen J, Zhang H, Deng A (2020b) Association of reninangiotensin system inhibitors with severity or risk of death in patients with hypertension hospitalized for Coronavirus Disease 2019 (COVID-19) infection in Wuhan. China. JAMA Cardiol. https://doi.org/10.1001/jamacardio.2020.1624

Li Y, Wang M, Zhou Y, Chang J, Xian Y, Mao L, Hong C, Chen S, Wang Y, Wang H, Li M, Jin H, Bo H (2020c) Acute cerebrovascular disease following COVID-19: A Single Center, Retrospective, Observational Study (3/3/2020). SSRN: https://ssrn.com/abstr act $=3550025$ or https://dx.doi.org/10.2139/ssrn. 3550025

Li B, Yang J, Zhao F, Zhi L, Wang X, Liu L, Bi Z, Zhao Y (2020d) Prevalence and impact of cardiovascular metabolic diseases on COVID-19 in China. Clin Res Cardiol. https://doi.org/10.1007/ s00392-020-01626-9

Liu Y, Huang F, Xu J, Yang P et al (2020a) Anti-hypertensive Angiotensin II receptor blockers associated to mitigation of disease severity in elderly COVID-19 patients. medRxiv https://doi. org/10.1101/2020.03.20.20039586

Liu Y, Yang Y, Zhang C, Huang F, Wang F, Yuan J, Wang Z, Li J, Li J, Feng C, Zhang Z, Wang L, Peng L, Chen L, Qin Y, Zhao D, Tan S, Yin L, Xu J, Zhou C, Jiang C, Liu L (2020b) Clinical and biochemical indexes from 2019-nCoV infected patients linked to viral loads and lung injury. Sci China Life Sci 63:364-374. https ://doi.org/10.1007/s11427-020-1643-8

Mao L, Wang M, Chen S, He Q, Chang J, Hong C, Zhou Y, Wang D, Miao X, Hu Y, Li Y (2020) Neurological manifestations of hospitalized patients with COVID-19 in Wuhan, China: a retrospective case series study. medRxiv, 2020.02.22.20026500. https ://doi.org/10.1101/2020.02.22.20026500

Marin C, Vilas D, Langdon C, Alobid I, López-Chacón M, Haehner A, Hummel T, Mullol J (2018) Olfactory dysfunction in neurodegenerative diseases. Curr. Allergy Asthma Rep 18:42. https:// doi.org/10.1007/s11882-018-0796-4

Markus HS, Brainin M (2020) EXPRESS: COVID-19 and Stroke-A Global World Stroke Organisation perspective. Int J Stroke. https ://doi.org/10.1177/1747493020923472

Matsuyama S, Nagata N, Shirato K, Kawase M, Takeda M, Taguchi F (2010) Efficient activation of the severe acute respiratory syndrome coronavirus spike protein by the transmembrane protease TMPRSS2. J Virol 84:12658-12664. https://doi.org/10.1128/ JVI.01542-10

Meng J, Xiao G, Zhang J, He X, Ou M, Bi J, Yang R, Di W, Wang Z, Li Z, Gao H, Liu L, Zhang G (2020) Renin-angiotensin system inhibitors improve the clinical outcomes of COVID-19 patients with hypertension. Emerg Microbes Infect 9:757-760. https://doi. org/10.1080/22221751.2020.1746200

Monteil V, Kwon H, Prado P, Hagelkrüys A, Wimmer RA, Stahl M, Leopoldi A, Garreta E, Hurtado del Pozo C, Prosper F, Romero JP, Wirnsberger G, Zhang H, Slutsky AS, Conder R, Montserrat N, Mirazimi A, Penninger JM (2020) Inhibition of SARS-CoV-2 infections in engineered human tissues using clinical-grade soluble human ACE2. Cell. https://doi.org/10.1016/j.cell.2020.04.004 
Mortensen EM, Nakashima B, Cornell J, Copeland LA, Pugh MJ, Anzueto A, Good C, Restrepo MI, Downs JR, Frei CR, Fine MJ (2012) Population-based study of statins, angiotensin II receptor blockers, and angiotensin-converting enzyme inhibitors on pneumonia-related outcomes. Clin Infect Dis 55:1466-1473. https:// doi.org/10.1093/cid/cis733

Netland J, Meyerholz DK, Moore S, Cassell M, Perlman S (2008) Severe acute respiratory syndrome coronavirus infection causes neuronal death in the absence of encephalitis in mice transgenic for human ACE2. J Virol 82:7264-7275. https://doi.org/10.1128/ JVI.00737-08

Patel AB, Verma A (2020) COVID-19 and angiotensin-converting enzyme inhibitors and angiotensin receptor blockers what is the evidence? JAMA. https://doi.org/10.1001/jama.2020.4812

Paul M, Poyan Mehr A, Kreutz R (2006) Physiology of local reninangiotensin systems. Physiol Rev 86:747-803. https://doi. org/10.1152/physrev.00036.2005

Peña Silva RA, Chu Y, Miller JD, Mitchell IJ, Penninger JM, Faraci FM, Heistad DD (2012) Impact of ACE2 deficiency and oxidative stress on cerebrovascular function with aging. Stroke 43:3358 3363. https://doi.org/10.1161/STROKEAHA.112.667063

Poyiadji N, Shahin G, Noujaim D, Stone M, Patel S, Griffith B (2020) COVID-19-associated acute hemorrhagic necrotizing encephalopathy: CT and MRI features. Images Radiol. https://doi. org/10.1148/radiol.2020201187

Qi F, Qian S, Zhang S, Zhang Z (2020) Single cell RNA sequencing of 13 human tissues identify cell types and receptors of human coronaviruses. Biochem Biophys Res Commun. https://doi. org/10.1016/j.bbrc.2020.03.044

Rabin R (2020) Some Coronavirus patients show signs of brain ailments. The New York Times, April 1.

Readhead B, Haure-Mirande JV, Funk CC, Richards MA, Shannon P, Haroutunian V, Sano M, Liang WS, Beckmann ND, Price ND, Reiman EM, Schadt EE, Ehrlich ME, Gandy S, Dudley JT (2018) Multiscale analysis of independent Alzheimer's cohorts finds disruption of molecular, genetic, and clinical networks by human herpesvirus. Neuron 99:64-82.e7. https://doi.org/10.1016/j.neuro n.2018.05.023

Rein J, Bader M (2017) Renin-angiotensin system in diabetes. Protein Pept Lett 24:833-840. https://doi.org/10.2174/092986652466617 0728144357

Ren L, Lu X, Danser AHJ (2019) Revisiting the brain renin-angiotensin system-focus on novel therapies. Curr Hypertens Rep 21:28. https ://doi.org/10.1007/s11906-019-0937-8

Rodriguez-Perez AI, Sucunza D, Pedrosa MA, Garrido-Gil P, Kulisevsky J, Lanciego JL, Labandeira-Garcia JL (2018) Angiotensin type receptor antagonists protect against alpha-synucleininduced neuroinflammation and dopaminergic neuron death. Neurotherapeutics 15:1063-1081. https://doi.org/10.1007/s1331 1-018-0646-Z

Rodrigues Prestes TR, Rocha NP, Miranda AS, Teixeira AL, SimoesE-Silva AC (2017) The anti-inflammatory potential of ACE2/ angiotensin-(1-7)/Mas receptor axis: evidence from basic and clinical research. Curr Drug Targets 18:1301-1313. https://doi. org/10.2174/1389450117666160727142401

Saavedra JM (2017) Beneficial effects of Angiotensin II receptor blockers in brain disorders. Pharmacol Res 125:91-103. https://doi. org/10.1016/j.phrs.2017.06.017

Saavedra JM (2020) Angiotensin receptor blockers and COVID19. Pharmacol Res 156:104832. https://doi.org/10.1016/j. phrs.2020.104832
Setiadi A, Korim WS, Elsaafien K, Yao ST (2018) The role of the blood-brain barrier in hypertension. Exp. Physiol. 103:337-342. https://doi.org/10.1113/EP086434

Schmieder RE (2005) Mechanisms for the clinical benefits of angiotensin II receptor blockers. Am J Hypertens 18:720-730. https:// doi.org/10.1016/j.amjhyper.2004.11.032

Shang J, Ye G, Shi K, Wan Y, Luo C, Aihara H, Geng Q, Auerbach A, Li F (2020) Structural basis of receptor recognition by SARSCoV-2. Nature. https://doi.org/10.1038/s41586-020-2179-y

Sharifi-Razavi A, Karimi N, Rouhani N (2020) COVID 19 and Intra cerebral hemorrhage: causative or coincidental. New Microbes New Infect. https://doi.org/10.1016/j.nmni.2020.100669

Soto M, Bang SI, McCombs J, Rodgers KE (2017) Renin Angiotensin system-modifying therapies are associated with improved pulmonary health. Clin Diabetes Endocrinol 3:6. https://doi. org/10.1186/s40842-017-0044-1

South AM, Diz DI, Chappell MC (2020) COVID-19, ACE2 and the cardiovascular consequences. Invited Perspective "COVID-19, ACE2...". Am J Physiol Heart Circ Physiol 318:H1084-1090. https://doi.org/10.1152/ajpheart.00217.2020

Suzuki M, Saito K, Min WP, Vladau C, Toida K, Itoh H, Murakami S (2007) Identification of viruses in patients with postviral olfactory dysfunction. Laryngoscope 117:272-277. https://doi. org/10.1097/01.mlg.0000249922.37381.1e

Takimoto-Ohnishi E, Murakami K (2019) Renin-angiotensin system research: from molecules to the whole body. J Physiol Sci 69:581587. https://doi.org/10.1007/s12576-019-00679-4

Vaduganathan M, Vardeny O, Michel T, McMurray JJV, Pfeffer MA, Solomon SD (2020) Renin-angiotensin-aldosterone system inhibitors in patients with COVID-19. N Engl J Med 382:1653-1659. https://doi.org/10.1056/NEJMsr2005760

Villapol S, Saavedra JM (2015) Neuroprotective effects of angiotensin receptor blockers. Am J Hypertens 28:289-299. https://doi. org/10.1093/ajh/hpu197

Warner FJ, Smith AI, Hooper NM, Turner AJ (2004) Angiotensinconverting enzyme-2: a molecular and cellular perspective. Cell Mol Life Sci 61:2704-2713. https://doi.org/10.1007/s0001 8-004-4240-7

Weiss SR, Navas-Martin S (2005) Coronavirus pathogenesis and the emerging pathogen severe acute respiratory syndrome coronavirus. Microbiol Mol Biol Rev 69:635-664. https://doi.org/10.1128/ MMBR.69.4.635-664.2005

Wysocki J, Ye M, Rodriguez E, Gonzalez-Pacheco FR, Barrios C, Evora K, Schuster M, Loibner H, Brosnihan KB, Ferrario CM, Penninger JM, Batlle D (2010) Targeting the degradation of angiotensin II with recombinant angiotensin-converting enzyme 2: prevention of angiotensin II-dependent hypertension. Hypertension 55:90-98. https://doi.org/10.1161/HYPERTENSIONAHA .109 .138420

Yamagata R, Nemoto W, Nakagawasai O, Takahashi K, Tan-No K (2020) Downregulation of spinal angiotensin converting enzyme 2 is involved in neuropathic pain associated with type 2 diabetes mellitus in mice. Biochem Pharmacol 174:113825. https://doi. org/10.1016/j.bcp.2020.113825

Yan R, Zhang Y, Li Y, Xia L, Guo Y, Zhou Q (2020) Structural basis for the recognition of SARS-CoV-2 by full-length human ACE2. Science 367:1444-1448. https://doi.org/10.1126/science.abb2762

Yeager A (2020a) Lost smell and taste hint COVID-19 can target the nervous system. The Scientist, March 24

Yeager A (2020b) Blood pressure meds point the way to possible COVID-19 treatment. The Scientist, April 2 
Yu X, Lin Q, Qin X, Ruan Z, Zhou J, Lin Z, Su Y, Zheng J, Liu Z (2016) ACE2 antagonizes VEGFa to reduce vascular permeability during acute lung injury. Cell Physiol Biochem 38:1055-1062. https://doi.org/10.1159/000443056

Xu J, Mukerjee S, Silva-Alves CR, Carvalho-Galvão A, Cruz JC, Balarini CM, Braga VA, Lazartigues E, França-Silva MS (2016) A disintegrin and metalloprotease 17 in the cardiovascular and central nervous systems. Front Physiol 7:469. https://doi.org/10.3389/ fphys.2016.00469

Ziegler CGK, Allon SJ, Nyquist SK, Mbano IM et al (2020) SARSCoV-2 receptor ACE2 is an interferon-stimulated gene in human airway epithelial cells and is detected in specific cell subsets across tissues. Cell-D-20-00767. https://doi.org/10.1016/j. cell.2020.04.035

Zou X, Chen K, Zou J, Han P, Hao J, Han Z (2020) Single-cell RNAseq data analysis on the receptor ACE2 expression reveals the potential risk of different human organs vulnerable to $2019-\mathrm{nCoV}$ infection. Front Med. https://doi.org/10.1007/s11684-020-0754-0

Publisher's Note Springer Nature remains neutral with regard to jurisdictional claims in published maps and institutional affiliations. 